\title{
Pendapatan, Pendidikan, Persepsi Kemudahan, dan Sikap sebagai Mediasi terhadap Keputusan Penggunaan Mobile Banking Syari’ah
}

\author{
Rosilia Salmah $^{1)}$, Luqman Hakim ${ }^{2 *}$ \\ ${ }^{1,2}$ Fakultas Ekonomi, Universitas Negeri Surabaya \\ *Email korespondensi : luqmanhakim@unesa.ac.id
}

\begin{abstract}
The existence of Covid-19 which limited society to transact online has made an increment several islamic banks in users and the number of transactions. The aim of this study was to review test how the influence of income, education, and perceived ease of use through attitude against the usage decision of shari'a mobile banking. A Structural Equation Model (SEM) was used to analyze in this study with WarpPLS 7.0 approach. Respondent of this research was general public of Surabaya City. Sampling technique which used in this study was purposive sampling as many as 115 respondents. The result present that perceived ease of use is the most significant factor affecting usage decision and attitude towards mobile banking directly. For the indirect test, perceived ease of use is able to influence the usage decision through attitude. Education and income not significantly influence the usage decision and attitude towards mobile banking directly, neither indirectly.
\end{abstract}

Abstract

Keywords : income; education; ease of use; attitude; shari'a mobile banking

Saran sitasi: Salmah, R., \& Hakim, L. (2021). Pendapatan, Pendidikan, Persepsi Kemudahan, dan Sikap sebagai Mediasi terhadap Keputusan Penggunaan Mobile Banking Syari'ah. Jurnal Ilmiah Ekonomi Islam, 7(02), 798805. doi: http://dx.doi.org/10.29040/jiei.v7i2.2473

DOI: http://dx.doi.org/10.29040/jiei.v7i2.2473

\section{PENDAHULUAN}

Hadirnya Pandemi Covid-19 menyebabkan Pembatasan Sosial Berskala Besar (PSBB) dilakukan di Surabaya sejak 28 April 2020 hingga 25 Mei 2020 yang berdampak pada berbagai hal. Turunnya penghasilan masyarakat merupakan salah satu dampak yang dirasa. Hingga Juni 2020, di Kota Surabaya tercatat dilakukan Pemutusan Hubungan Kerja (PHK) terhadap 497 orang, dan sebanyak 1.594 orang terpaksa dirumahkan (Sal/c6/ano, 2020). Selain pekerjaan, hal ini berdampak pula pada kebebasan bertransaksi secara luar jaringan (luring) oleh pelaku ekonomi. Terlebih lagi, adanya pandemi Covid-19 di Indonesia bertepatan dengan hari besar islam seperti Idul Fitri dan Idul Adha membuat masyakarat Surabaya yang $85,1 \%$ penduduknya merupakan umat muslim (Pintu, n.d.) memiliki keterbatasan bertransaksi secara luring dalam rangka membayar zakat dan infaq, membeli hewan kurban, pelunasan haji, serta pembukaan rekening.

Pada akhirnya, banyak nasabah lembaga keuangan bank beralih menggunakan mobile banking dalam mempermudah transaksi, terutama mobile banking syari'ah. Hingga Juni 2020, tercatat kenaikan sebesar 93,89\% pengguna Mandiri Syari'ah Mobile (MSM) dengan transaksi yang melonjak pula sebesar 19,49 juta transaksi (Zuraya \& Puspaningtyas, n.d.). Hal serupa dialami pula oleh Bank BCA Syari'ah. Sebelum masa pandemi, total keseluruhan pengguna BCA Syari'ah Mobile hanya sebanyak 25.100 pengguna, namun saat terjadinya pandemi, melonjak sebesar 46\% menjadi 36.700 pengguna (Budiawati, 2020).

Keputusan penggunaan mobile banking syari'ah sebagai teknologi informasi dipengaruhi oleh berbagai faktor, salah satunya persepsi kemudahan. Hal ini sejalan dengan teori Technology Acceptance Model (TAM) yang diusung oleh Davis dkk pada 1989 dengan tiga indikator, di antaranya adalah kemudahan mempelajari mobile banking, tidak membutuhkan usaha mental dalam mempelajarinya, serta mampu mengikuti prosedur dalam aktivitas perbankan melalui mobile banking (Akturan \& Tezcan, 2012). Penelitian Pratiwi (2020) menemukan bahwa determinan utama 
dalam penggunaan digital banking adalah persepsi kemudahan. Penelitian terdahulu oleh Koksal (2016), Lestari (2018), Mentari (2018), dan Maduku (2013) menemukan bahwa persepsi kemudahan sangat memengaruhi keputusan penggunaan mobile banking secara signifikan. Semakin seseorang merasakan kemudahan dalam penggunaan mobile banking, maka semakin mudah pula memutuskan menggunakan mobile banking.

Kemudahan yang dirasakan oleh seseorang dalam menggunakan suatu teknologi akan berpengaruh pula terhadap sikap seseorang dalam menggunakan teknologi (Anouze \& Alamro, 2019; Gbongli et al., 2019; Maduku, 2013; Oyeleye et al., 2015; Zhang et al., 2018). Sikap positif tersebut meliputi timbulnya perasaan senang, adanya anggapan bahwa mobile banking diinginkan oleh banyak orang, keputusan yang bijaksana, serta ide yang baik (Akturan \& Tezcan, 2012). Sehingga, semakin seseorang merasakan kemudahan penggunaan, semakin timbul sikap positif yang dirasakan. Sikap dalam penggunaan teknologi tersebut juga mampu memengaruhi keputusan penggunaan teknologi (Akturan \& Tezcan, 2012; Gbongli et al., 2019; Gupta \& Varma, 2019; Maduku, 2013; Onyia \& Tagg, 2011; Santouridis \& Kyritsi, 2014). Apabila seseorang merasakan keempat sikap positif tersebut, maka keputusan untuk menggunakan teknologi akan semakin besar.

Penelitian lain justru mengungkapkan tidak adanya pengaruh yang signifikan persepsi kemudahan dengan keputusan penggunaan (Hadi \& Novi, 2015; Mohd Thas Thaker et al., 2019). Ditemukan pula bahwa tidak adanya pengaruh persepsi kemudahan terhadap sikap dalam penggunaan teknologi (Akturan \& Tezcan, 2012; Gupta \& Varma, 2019; Ho et al., 2020).

Moon dan Kim (2001) mengatakan bahwa tidak sepenuhnya konstruksi dalam TAM mencerminkan beberapa pengaruh dalam teknologi dan penggunaannya. Oleh karena itu, Maduku (2013) dalam penelitiannya menambahkan variabel Demografi yang terdiri dari pendidikan, pendapatan, dan usia untuk menganalisis faktor-faktor yang memengaruhi penggunaan suatu teknologi terutama dalam dunia perbankan. Dari hasil penelitian tersebut, disebutkan bahwa tingkat pendidikan seseorang memengaruhi penggunaan mobile banking secara signifikan. Orang-orang yang berpendidikan tinggi memiliki sikap positif terhadap penggunaan teknologi.
Selain adanya pengaruh yang signifikan tingkat pendidikan terhadap keputusan penggunaan mobile banking (Gupta \& Varma, 2019; Izogo \& Nnaemeka, 2012; KÖSE \& GÜLERYÜZ, 2020), ditemukan pula bahwa tingkat pendidikan memiliki pengaruh yang kuat terhadap sikap (Buchari et al., 2015; Gupta \& Varma, 2019; Maduku, 2013). Namun, penelitian Koksal (2016) dan Lozada (2019) justru menemukan hal yang bertentangan. Dalam penelitiannya, pendidikan justru tidak memengaruhi terhadap keputusan penggunaan mobile banking secara signifikan. Penelitian Oyeleye (2015) dan Johara (2014) juga ditemukan bahwa tingkat pendidikan seseorang tidak berpengaruh terhadap sikap seseorang dalam keputusan penggunaan online banking.

Selain tingkat pendidikan, salah satu faktor yang memengaruhi penggunaan mobile banking adalah tingkat pendapatan (KÖSE \& GÜLERYÜZ, 2020; Mehmet Haluk Koksal, 2016; R. Lozada \& H. Kritz, 2019). Pendapatan yang dimaksudkan dalam hal ini adalah pendapatan dalam keluarga berupa imbalan atas kegiatan ekonomi yang dilakukan dengan menggunakan faktor produksi, yang terdiri dari upah, gaji, sewa, bunga, deviden, komisi, honor, serta laba (Eryanto \& Swaramarinda, 2013). Penelitian yang dilakukan Johara (2014) juga menambahkan variabel kelas sosioekonomi, mengemukakan bahwa kelas sosial ekonomi memiliki pengaruh yang signifikan terhadap sikap penggunaan mobile banking. Dalam penelitiannya, responden sosial ekonomi menengah keatas dengan tingkat pendapatan yang tinggi lebih cenderung terbuka dalam penerimaan teknologi. Sebaliknya, penelitian Izogo (2012) justru menemukan bahwa tidak adanya pengaruh pendapatan dengan keputusan penggunaan mobile banking. Begitu juga temuan lain yang menyatakan bahwa pendapatan tidak memengaruhi sikap secara signifikan pada penggunaan mobile banking (Buchari et al., 2015; Onyia \& Tagg, 2011).

Dari argumen dan deskripsi tersebut, diperoleh tujuan dari penelitian ini untuk menguji pengaruh pendapatan, pendidikan, dan persepsi kemudahan melalui sikap terhadap keputusan penggunaan mobile banking syari'ah.

\section{METODE PENELITIAN}

Penelitian ini merupakan penelitian kuantitatif melalui pendekatan kausalitas. Melalui penelitian ini, dapat diketahui hubungan sebab akibat antarvariabel, di antaranya adalah variabel eksogen yang tediri dari 
pendapatan $\left(X_{1}\right)$, tingkat pendidikan $\left(X_{2}\right)$, dan persepsi kemudahan $\left(X_{3}\right)$, serta variabel endogen yang terdiri dari keputusan penggunaan $(Y)$, dan sikap $(Z)$.

Penelitian ini dilakukan di Kota Surabaya dengan populasi penelitian masyarakat pengguna mobile banking syari'ah di Surabaya, dan teknik pengambilan sampel adalah purposive sampling, yang di dalamnya diperlukan beberapa kriteria. Kriteria tersebut meliputi responden nasabah bank syari'ah pengguna mobile banking syari'ah yang telah memiliki pendapatan dan berdomisili di Kota Surabaya. Adapun banyaknya sampel penelitian sebanyak 115 responden. Penentuan jumlah sampel berdasarkan Ferdinand dalam (Yasa et al., 2014) yang menyatakan bahwa banyaknya sampel dalam sebuah penelitian berdasarkan 5-10 kali jumlah indikator dalam variabel penelitian. Sedangkan, jumlah indikator dalam variabel penelitian ini sebanyak 10 indikator, sehingga sepuluh indikator dikalikan sepuluh diperoleh 100. Namun, jumlah kuesioner yang terisi sebanyak 115 , oleh karena itu, peneliti menggunakan 115 responden.

Sumber data pada penelitian ini adalah data primer yang didapat melalui instrumen penelitian berupa kuesioner dengan menggunakan skala likert. Guna mendapatkan instrumen penelitian yang layak, maka dilakukan pengujian terlebih dahulu validitas dan reliabilitasnya. Sehingga, peneliti melakukan pilot test dengan melibatkan responden sebanyak 30 orang dengan aplikasi IBM Statistics 25. Hasil pilot test disajikan melalui tabel di bawah ini.

Tabel 1. Validitas Pilot Test

\begin{tabular}{cccc}
\hline Indikator & R hitung & R tabel & Ket \\
\hline PK1 & 0,905 & 0,361 & Valid \\
\hline PK2 & 0,817 & 0,361 & Valid \\
\hline PK3 & 0,911 & 0,361 & Valid \\
\hline KP1 & 0,664 & 0,361 & Valid \\
\hline KP2 & 0,502 & 0,361 & Valid \\
\hline KP3 & 0,870 & 0,361 & Valid \\
\hline SKP1 & 0,737 & 0,361 & Valid \\
\hline SKP2 & 0,864 & 0,361 & Valid \\
\hline SKP3 & 0,855 & 0,361 & Valid \\
\hline SKP4 & 0,775 & 0,361 & Valid \\
\hline
\end{tabular}

Dari tabel di atas, setiap indikator memiliki nilai $\mathrm{R}$ hitung yang lebih tinggi dari $\mathrm{R}$ tabel. Sebuah kuesioner dapat dikatakan valid apabila setiap butir pertanyaan memiliki koefisien korelasi $\mathrm{R}$ hitung lebih tinggi dari R tabel (Periyadi, Sri Bulkia, 2020). Hal ini berarti bahwa sudah memenuhi persyaratan dari indikator yang dinyatakan valid.
Untuk reliabilitas dari masing-masing variabel, diperoleh hasil $\mathrm{R}$ tabel sebesar 0,361, dan diperoleh nilai alpha cronbach sebesar 0,851 untuk variabel PK; 0,451 untuk variabel $\mathrm{KP}$; dan 0,821 untuk variabel SKP. Apabila nilai cronbach alpha dalam masingmasing variabel telah melebihi nilai $\mathrm{R}$ tabel, maka dinyatakan reliabel (Periyadi, Sri Bulkia, 2020).

Teknik analisis data dalam penelitian ini menggunakan Structural Equation Model (SEM) yang ditujukan untuk mengetahui hubungan antarvariabel eksogen dan juga endogen dengan menggunakan aplikasi WarpPLS 7.0. Rancangan penelitian dapat digambarkan sebagai berikut :

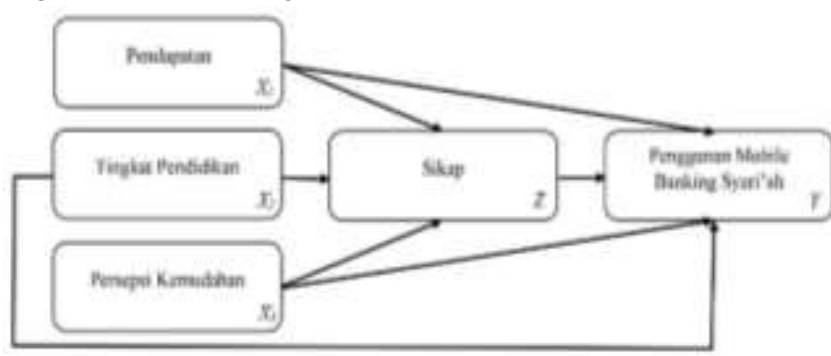

Gambar 1. Rancangan Penelitian

\section{HASIL DAN PEMBAHASAN}

\subsection{Hasil penelitian}

Dari hasil pengujian hipotesis dengan analisis SEM dan pendekatan WarpPLS 7.0, dapat disajikan gambar berikut :

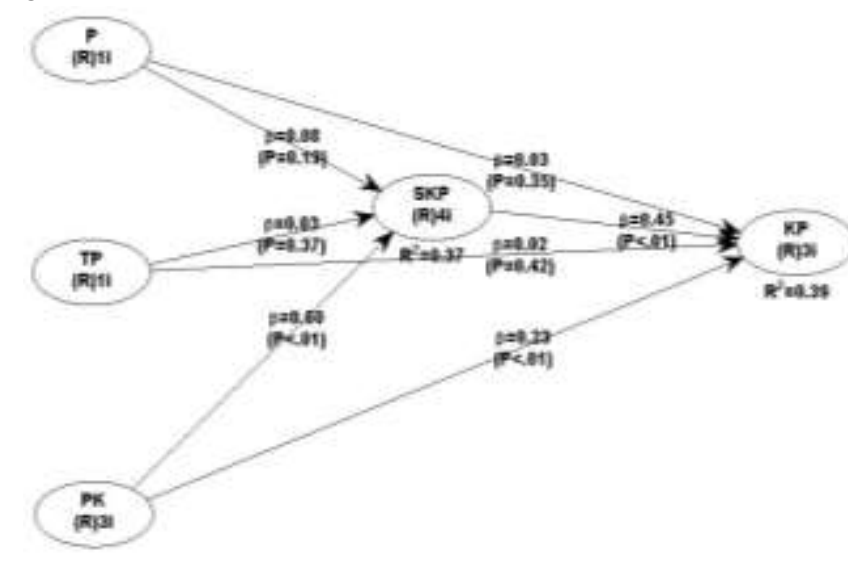

Gambar 2. Output Model Pengukuran

\section{Evaluasi outer model}

Dalam evaluasi outer model, dilakukan tiga pengujian. Yang pertama adalah validitas konvergen. Pengukuran didasarkan pada nilai loading pada setiap indikator penelitian. Apabila nilai loading lebih besar dari 0,5 ; serta signifikan $(\rho<0,01)$ maka variabel penelitian ini memenuhi validitas konvergen (Bria et al., 2020). Hasil perhitungan nilai loading pada masing-masing indikator dapat diketahui melalui tabel berikut, 
Jurnal Ilmiah Ekonomi Islam, 7(02), 2021, 801

Tabel 2. Nilai Loading Validitas Konvergen

\begin{tabular}{ccc}
\hline Indikator & Nilai Loading & $\rho$-value \\
\hline P & 1,000 & $<0,001$ \\
\hline TP & 1,000 & $<0,001$ \\
PK1 & 0,922 & $<0,001$ \\
\hline PK2 & 0,852 & $<0,001$ \\
\hline PK3 & 0,893 & $<0,001$ \\
\hline KP1 & 0,701 & $<0,001$ \\
\hline KP2 & 0,805 & $<0,001$ \\
\hline KP3 & 0,655 & $<0,001$ \\
\hline SKP1 & 0,776 & $<0,001$ \\
\hline SKP2 & 0,844 & $<0,001$ \\
\hline SKP3 & 0,843 & $<0,001$ \\
\hline SKP4 & 0,768 & $<0,001$ \\
\hline
\end{tabular}

Berdasarkan tabel di atas, dapat disimpulkan setiap indikator dalam penelitian ini telah valid.

Setelah validitas konvergen, pengujian yang kedua adalah pengujian validitas diskriminan. Dalam pengujian ini, nilai $A V E$ setiap indikator harus lebih besar dari koefisien korelasi variabel yang bersangkutan (Bria et al., 2020). Berikut ini merupakan tabel perolehan nilai $A V E$ dan koefisien korelasi.

Tabel 3. Nilai AVE dan Koefisien Korelasi

\begin{tabular}{cccccc}
\hline & P & TP & PK & SKP & KP \\
\hline P & $(1,000)$ & 0,002 & 0,127 & 0,100 & 0,089 \\
\hline TP & 0,002 & $(1,000)$ & 0,056 & 0,068 & 0,076 \\
\hline PK & 0,127 & 0,056 & $(0,889)$ & 0,504 & 0,592 \\
\hline SKP & 0,100 & 0,068 & 0,504 & $(0,723)$ & 0,589 \\
\hline KP & 0,089 & 0,076 & 0,592 & 0,589 & $(0,809)$ \\
\hline
\end{tabular}

Tabel 3 menunjukkan bahwa nilai AVE lebih besar dari koefisien korelasi, yang berarti bahwa kelima variabel telah memenuhi validitas diskriminan.

Pengujian yang terakhir pada evaluasi outer model adalah pengujian composite reliability. Diperoleh nilai composite reliability sebesar 1,000 untuk variabel $\mathrm{P}$ dan TP; 0,919 untuk variabel $\mathrm{PK}$; 0,765 untuk variabel SKP; serta 0,883 untuk variabel KP. Apabila composite reliability lebih besar dari 0,7; dapat diartikan bahwa reliabilitas indikator dinyatakan baik (Bria et al., 2020).

\section{Evaluasi Inner Model}

Evaluasi inner model, dilakukan dengan melihat besar nilai pada Model Fit and Quality Indices dengan memperhatikan nilai ideal pada masing-masing indikator. Selain itu, $\mathrm{R}^{2}$ dan nilai Goodness of Fit (GoF) juga menjadi evaluasi pada inner model.
Melalui tabel di bawah ini, dapat dilihat nilai dari pengujian model fit and indices.

Tabel 4. Model Fit and Indices

\begin{tabular}{lcc}
\hline \multicolumn{1}{c}{ Indikator } & Hasil & Ideal \\
\hline$A P C$ & 0,$206 ; \rho=0,005$ & $\rho<0,05$ \\
\hline$A R S$ & 0,$383 ; \rho<0,001$ & $\rho<0,05$ \\
\hline$A A R S$ & 0,$364 ; \rho<0,001$ & $P<0,05$ \\
\hline$A V I F$ & 1,111 & $\leq 5$ \\
\hline$A F V I F$ & 1,433 & $\leq 5$ \\
\hline GoF & 0,554 & Large \\
\hline$S P R$ & 1,000 & $\geq 0,7$ \\
\hline$R S C R$ & 1,000 & $\geq 0,9$ \\
\hline$S S R$ & 1,000 & $\geq 0,7$ \\
\hline$N L B C D R$ & 0,786 & $\geq 0,7$ \\
\hline
\end{tabular}

Pada tabel di atas, dapat dilihat bahwa kesepuluh indikator memenuhi nilai ideal, serta diketahui nilai GoF sebesar 0,554 di mana nilai tersebut tergolong nilai yang besar dalam ukuran $G o F$.

Pengujian dalam evaluasi inner model yang selanjutnya adalah nilai $\mathrm{R}^{2}$. Dalam variabel Sikap, diperoleh nilai $R^{2}$ sebesar 0,374 . Sedangkan, dalam variabel Keputusan Penggunaan, nilai $\mathrm{R}^{2}$ mencapai 0,392. Dapat disimpulkan bahwa keputusan penggunaan mobile banking syari'ah dipengaruhi pendapatan, pendidikan, dan persepsi kemudahan sebesar $37,4 \%$; sedangkan $62,6 \%$ dipengaruhi oleh variabel lain di luar model ini. Berikutnya, sikap dipengaruhi oleh pendapatan, pendidikan, dan persepsi kemudahan sebesar 39,2\%; sedangkan 60,8\% lainnya dipengaruhi oleh variabel di luar model ini.

\section{Uji Hipotesis}

Pengujian hipotesis dilakukan dengan dua cara, yang pertama adalah dengan inner model untuk mengetahui pengaruh secara langsung, serta outer model untuk pengaruh secara tidak langsung. Melalui tabel 4 , dapat diketahui hasil uji hipotesis melalui inner model.

Tabel 5. Uji Hipotesis melalui Inner Model

\begin{tabular}{cccc}
\hline Variabel & $\begin{array}{c}\text { Koefisien } \\
\text { Jalur }\end{array}$ & $\rho$-value & Ket \\
\hline $\mathrm{P} \rightarrow$ SKP & 0,046 & 0,311 & Tidak \\
\hline $\mathrm{TP} \rightarrow \mathrm{SKP}$ & 0,036 & 0,348 & Tidak \\
\hline $\mathrm{PK} \rightarrow \mathrm{SKP}$ & 0,500 & $<0,001$ & Signifikan \\
\hline $\mathrm{P} \rightarrow \mathrm{KP}$ & 0,043 & 0,319 & Tidak \\
\hline $\mathrm{TP} \rightarrow \mathrm{KP}$ & 0,037 & 0,345 & Tidak \\
\hline $\mathrm{PK} \rightarrow \mathrm{KP}$ & 0,378 & $<0,001$ & Siginifikan \\
\hline $\mathrm{SKP} \rightarrow \mathrm{KP}$ & 0,435 & $<0,001$ & Signifikan \\
\hline
\end{tabular}




\section{Jurnal Ilmiah Ekonomi Islam, 7(02), 2021, 802}

Selanjutnya adalah hasil dari pengujian hipotesis melalui outer model untuk mengetahui adakah pengaruh signifikan secara tidak langsung. Dari hasil pengujian inner model antara variabel $\mathrm{X}$ terhadap $\mathrm{Y}$ ataupun $\mathrm{X}$ terhadap $\mathrm{Z}$ yang tidak memiliki pengaruh signifikan tidak dilibatkan dalam pengujian outer model. Hal ini sesuai dengan MacKinnon (MacKinnon, 2012) yang mengemukakan bahwa untuk membuktikan suatu variabel intervening, maka harus terdapat pengaruh signifikan antara $X$ terhadap $\mathrm{Z}$, serta $\mathrm{Z}$ terhadap $\mathrm{Y}$, meskipun $\mathrm{X}$ terhadap $\mathrm{Y}$ tidak memiliki hubungan yang signifikan.

Hubungan variabel yang diuji dalam pengujian hipotesis outer model dalam penelitian ini hanyalah PK, SKP, dan KP. Hasil dari pengujian outer model ketiga variabel $\mathrm{PK} \rightarrow \mathrm{SKP} \rightarrow \mathrm{KP}$ menghasilkan nilai koefisien jalur sebesar 0,218 dan $\rho$ value sebesar < 0,001 .

\subsection{Pembahasan}

Berdasarkan pengujian hipotesis melalui inner model dan outer model, didapatkan bahwa:

\section{Pengaruh Pendapatan terhadap Sikap}

Hasil pengujian pengaruh variabel pendapatan terhadap sikap menunjukkan nilai $\rho$-value sebesar 0,311 . Nilai $\rho$-value yang menunjukkan angka $>0,05$ menyatakan bahwa pendapatan tidak memengaruhi sikap secara signifikan. Hal ini sesuai penelitian terdahulu oleh Maduku (2013), Gupta (2019), dan Buchari (2015) yang menyatakan bahwa tidak adanya pengaruh pendapatan terhadap sikap dalam penggunaan mobile banking. Dengan begitu, hasil ini bertolak belakang dengan penelitian Johara (2014). Dalam penelitiannya, terdapat pengaruh antara kelompok sosial ekonomi berpendapatan tinggi dengan sikap dalam penggunaan online banking.

Masyarakat dengan pendapatan tinggi maupun rendah mampu merasakan sikap-sikap positif dalam penggunaan mobile banking syari'ah dikarenakan aktivitas keuangan yang diakses melalui mobile banking syari'ah mampu memberikan kepada mereka perasaan senang, pengetahuan mengenai fiqh mu'amalah, keyakinan selama menggunakan, serta berbagai keuntungan lainnya.

\section{Pengaruh Tingkat Pendidikan terhadap Sikap}

Nilai $\rho$-value dalam pengujian variabel pendidikan terhadap sikap sebesar 0,348. Dari hasil tersebut menyatakan tidak terdapat pengaruh signifikan tingkat pendapatan terhadap sikap. Hasil penelitian didukung oleh penelitian Oyeleye (2015) dan Johara (2014), namun berlawanan dengan teori yang digunakan sebelumnya (Buchari et al., 2015; Maduku, 2013; Onyia \& Tagg, 2011).

Sama halnya dengan pendapatan, dalam penelitian ini, tingkat pendidikan juga tidak memiliki pengaruh signifikan terhadap sikap. Hal ini dapat dikarenakan produk-produk bank syari'ah yang saat ini dapat dengan mudah dikenalkan dan digali informasinya kepada masyarakat umum, tanpa melalui pemrograman pada mata kuliah tertentu.

\section{Pengaruh Persepsi Kemudahan terhadap Sikap}

Pengujian pengaruh persepsi kemudahan terhadap sikap menghasilkan nilai $\rho$-value $<0,001$. Besar nilai $\rho$-value yang kurang dari 0,05 menunjukkan bahwa variabel persepsi kemudahan memengaruhi variabel sikap secara signifikan.

Penelitian Zhang (2018) dengan nilai $\beta$ persepsi kemudahan terhadap sikap sebesar 0,29 ; yang berarti menunjukan bahwa persepsi kemudahan memengaruhi sikap secara signifikan. Beberapa penelitian lain juga menemukan hal yang sama (Anouze \& Alamro, 2019; Gbongli et al., 2019; Maduku, 2013; Oyeleye et al., 2015). Namun, penelitian ini bertolak belakang dengan Ho (2020) dengan nilai $\rho$-value persepsi kemudahan terhadap sikap sebesar 0,099; serta penelitian oleh Akturan (2012) dan Gupta (2019).

\section{Pengaruh Pendapatan terhadap Keputusan Penggunaan}

Berdasarkan hasil pengujian pengaruh variabel Pendapatan terhadap keputusan penggunaan, menunjukkan nilai $\rho$-value sebesar 0,319. Hasil tersebut menunjukkan pendapatan tidak memengaruhi keputusan penggunaan secara signifikan.

Hasil penelitian ini didukung oleh Izogo (2012) yang mengungkapkan bahwa pendapatan tidak memiliki pengaruh signifikan terhadap keputusan penggunaan dengan $\rho$ value sbesar 0,9114 . Dengan begitu, hasil ini bertolak belakang dengan penelitian Lozada \& H. Kritz (2019) dalam penelitiannya juga mengungkapkan terdapat pengaruh signifikan pendapatan terhadap keputusan penggunaan dengan nilai signifikansi sebesar 0,004 dan dua penelitian lainnya (KÖSE \& GÜLERYÜZ, 2020; Mehmet Haluk Koksal, 2016). 


\section{Jurnal Ilmiah Ekonomi Islam, 7(02), 2021, 803}

Tidak adanya pengaruh signifikan antara pendapatan dengan keputusan penggunaan dalam penelitian ini dapat disebabkan karena keberadaan mobile banking syari'ah yang semakin marak di Indonesia. Sehingga, baik dari kalangan berpenghasilan rendah maupun tinggi, dapat dengan mudah mengenali bahkan mengakses fitur mobile banking dengan berbagai kepentingan transaksi setiap kelompok.

\section{Pengaruh Tingkat Pendidikan terhadap Keputusan Penggunaan}

Nilai $\rho$-value dalam pengujian variabel Tingkat Pendidikan terhadap Keputusan Penggunaan sebesar 0,345. Dari hasil tersebut menunjukkan tingkat pendidikan tidak memengaruhi keputusan penggunaan secara signifikan.

Sesuai dengan Koksal (2016) yang menyatakan tingkat pendidikan tidak memengaruhi keputusan penggunaan dengan $\beta$ sebesar 0,323 dan nilai signifikansi 0,657. Penelitian Lozada (2019) pun dengan nilai $\rho$ value lebih besar dari 0,05 menyatakan bahwa tidak adanya pengaruh yang signifikan antara tingkat pendidikan dengan keputusan penggunaan mobile banking. Sehingga, hasil penelitian ini bertolak belakang dengan Köse (2020) dengan nilai koefisien 0,430 yang berarti adanya pengaruh yang positif antara tingkat pendidikan dengan keputusan penggunaan. Izogo dan Nnaemeka (2012) juga mengungkapkan bahwa tingkat pendidikan seseorang berpengaruh terhadap keputusan penggunaan dengan nilai $\rho$ sebesar 0,0007 ; serta dua penelitian lainnya (Gupta \& Varma, 2019; Maduku, 2013).

Tidak adanya pengaruh tingkat pendidikan terhadap keputusan penggunaan mobile banking syari'ah dapat disebabkan oleh hadirnya revolusi industri 4.0 yang membuat masyarakat semakin dekat dengan keberadaan teknologi, sehingga baik dari kalangan berpendidikan tinggi maupun rendah telah mempu menjangkau penggunaan mobile banking. Terlebih lagi, saat penelitian ini dilakukan, bertepatan dengan hadirnya Pandemi Covid-19 yang memaksa semua masyarakat lebih sering menggunakan teknologi untuk beraktivitas, terutama dalam dunia pendidikan.

\section{Pengaruh Persepsi Kemudahan terhadap Keputusan Penggunaan}

Pengujian pengaruh persepsi kemudahan terhadap keputusan penggunaan menghasilkan nilai $\rho$ - value $<0,001$ yang berarti bahwa adanya pengaruh secara signifikan variabel persepsi kemudahan terhadap keputusan penggunaan. Hal ini didukung oleh penelitian Mentari (2018) dan Maduku (2013) dengan nilai T-Statistic masing-masing sebesar 5,825 dan 2,558. Lestari dan Rachmat (2018) juga menemukan dalam penelitiannya bahwa persepsi kemudahan memengaruhi keputusan penggunaan secara signifikan dengan nilai signifikansi sebesar 0,000. Selain itu, Koksal (2016) dalam penelitiannya menghasilkan nilai signifikansi sebesar 0,000 dan $\beta$ sebesar 1,158.

Hasil penelitian ini tidak sejalan dengan Mohd Thas Thaker (2019), di mana hasil pengaruh persepsi kemudahan terhadap keputusan penggunaan menghasilkan nilai $\beta$ sebesar 0,195 . Hadi dan Novi (2015) juga menemukan hal yang kontras dalam penelitiannya bahwa persepsi kemudahan tidak memengaruhi keputusan penggunaan secara signifikan dengan nilai $\beta \quad 0,038$ sebesar dan signifikansi 0,579 .

\section{Pengaruh Sikap terhadap Keputusan Penggunaan}

Berdasarkan hasil pengujian hipotesis pengaruh variabel Sikap terhadap Keputusan Penggunaan, menunjukkan nilai inner weight sebesar 0,435 dengan $\rho$-value sebesar $<0,001$. Pengujian ini menunjukkan variabel Sikap memengaruhi signifikan variabel Keputusan Penggunaan. Sehingga hasil ini sesuai dengan penelitian terdahulu (Akturan \& Tezcan, 2012; Gbongli et al., 2019; Gupta \& Varma, 2019; Ho et al., 2020; Maduku, 2013; Onyia \& Tagg, 2011). Sikap positif yang dihasilkan ketika menggunakan mobile banking mampu memengaruhi sesorang untuk dapat memutuskan tetap menggunakan karena berbagai keuntungan yang dirasakan.

\section{Pengaruh Persepsi Kemudahan terhadap Keputusan Penggunaan melalui Sikap}

Pengujian pengaruh persepsi kemudahan terhadap keputusan penggunaan melalui sikap menghasilkan nilai outer weight sebesar 0,218 degan nilai $\rho$-value $<0,001$. Besar nilai $\rho$-value $<0,05$ menunjukkan bahwa adanya pengaruh secara signifikan variabel persepsi kemudahan terhadap keputusan penggunaan. Hal ini sesuai dengan penelitian yang dilakukan oleh Gbongli (2019), dengan nilai $\beta$ sebesar 0,104 . Semakin tinggi kemudahan yang dirasakan dalam penggunaan mobile banking, semakin banyak pula sikap positif yang 


\section{Jurnal Ilmiah Ekonomi Islam, 7(02), 2021, 804}

dirasakan. Sehingga, hal itu tidak memberatkan seseorang dalam memutuskan untuk menggunakan mobile banking karena banyaknya keuntungan yang dirasakan.

\section{KESIMPULAN}

Dalam penelitian ini, dapat disimpulkan bahwa pendapatan dan tingkat pendidikan tidak memiliki pengaruh yang signifikan signifikan baik terhadap keputusan penggunaan maupun terhadap sikap dalam penggunaan mobile banking, sedangkan persepsi kemudahan merupakan faktor utama yang memengaruhi keputusan penggunaan mobile banking karena mampu memengaruhi keputusan penggunaan mobile banking baik secara langsung, maupun secara tidak langsung, yaitu melalui sikap.

\section{UCAPAN TERIMA KASIH}

Penulis mengucapkan banyak terimakasih kepada seluruh pihak yang telah bersedia membantu dan memberikan dukungan dalam bentuk apapun guna menyelesaikan penelitian ini.

\section{REFERENSI}

Akturan, U., \& Tezcan, N. (2012). Mobile banking adoption of the youth market: Perceptions and intentions. Marketing Intelligence and Planning, $30(4)$, 444-459. https://doi.org/10.1108/02634501211231928

Anouze, A. L. M., \& Alamro, A. S. (2019). Factors affecting intention to use e-banking in Jordan. International Journal of Bank Marketing, 38(1), 86-112. https://doi.org/10.1108/IJBM-10-20180271

Bria, M., Sutirto, S., \& Muda, A. H. (2020). Analisis Faktor-faktor yang Mempengaruhi Penentuan Jenis Pemeliharaan Embung Irigasi. Media Komunikasi Teknik Sipil, 25(2), 160. https://doi.org/10.14710/mkts.v25i2.20455

Buchari, I., Rafiki, A., \& Qassab, M. A. H. Al. (2015). Awareness and Attitudes of Employees towards Islamic Banking Products in Bahrain. Procedia Economics and Finance, 30(15), 68-78. https://doi.org/10.1016/s2212-5671(15)01256-3

Budiawati, A. D. (2020). Laba BCA Syariah Naik 8,7\%, Pengguna Mobile Banking Meningkat. Dream. https://www.dream.co.id/dinar/laba-bcasyariah-naik-87-pengguna-mobile-bankingmeningkat-200727u.html
Eryanto, H., \& Swaramarinda, D. R. (2013). Pengaruh Modal Budaya, Tingkat Pendidikan Orang Tua Dan Tingkat Pendapatan Orang Tua Terhadap Prestasi Akademik Pada Mahasiswa Fakultas Ekonomi Universitas Negeri Jakarta. Jurnal Pendidikan Ekonomi Dan Bisnis (JPEB), 1(1), 39. https://doi.org/10.21009/jpeb.001.1.3

Gbongli, K., Xu, Y., \& Amedjonekou, K. M. (2019). Extended technology acceptance model to predict mobile-based money acceptance and sustainability: A multi-analytical structural equation modeling and neural network approach. Sustainability (Switzerland), 11(13), 1-33. https://doi.org/10.3390/su11133639

Gupta, R., \& Varma, S. (2019). A structural equation model to assess behavioural intention to use biometric enabled e-banking services in India. International Journal of Business Information Systems, 31(4), 555-572. https://doi.org/10.1504/IJBIS.2019.101586

Hadi, S., \& Novi, N. (2015). Faktor-Faktor Yang Mempengaruhi Penggunaan Layanan Mobile Banking. Optimum: Jurnal Ekonomi Dan Pembangunan, 5(1), 55. https://doi.org/10.12928/optimum.v5i1.7840

Ho, J. C., Wu, C. G., Lee, C. S., \& Pham, T. T. T. (2020). Factors affecting the behavioral intention to adopt mobile banking: An international comparison. Technology in Society, 63(December 2019), 101360. https://doi.org/10.1016/j.techsoc.2020.101360

Izogo, E., \& Nnaemeka, O. (2012). Impact of Demographic Variables on Consumers' Adoption of E-banking in Nigeria: An Empirical Investigation. European Journal of ..., 4(17), 2739.

http://iiste.org/Journals/index.php/EJBM/article/ view/3199

Johara, F. T. (2014). Consumer's Pattern and Behavior toward the Usage of Mobile Banking. International Journal of Academic Research in Business and Social Sciences, 4(8), 166-181. https://doi.org/10.6007/ijarbss/v4-i8/1082

KÖSE, T., \& GÜLERYÜZ, E. H. (2020). Determinants of Internet Banking Adoption in Turkey. Journal of Yasar University, 15(58), 167-176. 


\section{Jurnal Ilmiah Ekonomi Islam, 7(02), 2021, 805}

Lestari, N. R., \& Rachmat, B. (2018). Faktor-Faktor Yang Mempengaruhi Keputusan Menggunakan Internet Banking Nasabah Bank Bri Di Surabaya. Journal of Business \& Banking, 8(1). https://doi.org/10.14414/jbb.v8i1.1003

MacKinnon, D. P. (2012). Introduction to Statistical Mediation Analysis. Introduction to Statistical Mediation Analysis, January 2008. https://doi.org/10.4324/9780203809556

Maduku, D. K. (2013). Predicting Retail Banking Customers' Attitude Towards Internet Banking Services in South Africa. Southern African Business Review, 17(3), 76-100.

Mehmet Haluk Koksal. (2016). The intentions of Lebanese consumers to adopt mobile banking. International Journal of Bank Marketing, 34(3), 327-346.

Mentari, A. D. (2018). Keamanan, Manfaat yang Dirasakan dengan Mediasi Persepsi Kemudahan Penggunaan terhadap Adopsi m-banking BRI Makassar Raya M-Banking. 157-175.

Mohd Thas Thaker, M. A. Bin, Allah Pitchay, A. Bin, Mohd Thas Thaker, H. Bin, \& Amin, M. F. Bin. (2019). Factors influencing consumers' adoption of Islamic mobile banking services in Malaysia: An approach of partial least squares (PLS). Journal of Islamic Marketing, 10(4), 1037-1056. https://doi.org/10.1108/JIMA-04-2018-0065

Moon, J. W., \& Kim, Y. G. (2001). Extending the TAM for a World-Wide-Web context. Information and Management, 38(4), 217-230. https://doi.org/10.1016/S0378-7206(00)00061-6

Onyia, O. P., \& Tagg, S. K. (2011). Effects of demographic factors on bank customers' attitudes and intention toward Internet banking adoption in a major developing African country. Journal of Financial Services Marketing, 16(34), 294-315. https://doi.org/10.1057/fsm.2011.28

Oyeleye, O., Sanni, M., \& Shittu, T. (2015). An investigation of the effects of customer's educational attainment on their adoption of Ebanking in Nigeria. Journal of Internet Banking and Commerce, 20(3). https://doi.org/10.4172/1204-5357.1000133
Periyadi, Sri Bulkia, R. (2020). Jieb: Jurnal Ilmiah Ekonomi Bisnis. Jurnal Ilmiah Ekonomi Bisnis (S4), 5(November), 1-12.

Pintu, D. P. M. dan P. T. S. (n.d.). Demografi. Retrieved October 15, 2020, from http://dpmptsp.surabaya.go.id/v3/pages/demografi

Pratiwi, I. E., Affandy, F. F., \& Rosalina, Y. (2020). Determinan Penggunaan Digital Banking Pada Generasi Milenial Muslim: Pendekatan Technology f Acceptance Model (Studi Kasus Di Kota Jayapura, Indonesia). Jurnal Ilmiah Ekonomi Islam, 6(3), 478. https://doi.org/10.29040/jiei.v6i3.1198

R. Lozada, H., \& H. Kritz, G. (2019). Net Neutrality Repeal and its Effect on Consumers. International Journal of Business and Social Science, $\quad 10(1), \quad 63-77$. https://doi.org/10.30845/ijbss.v10n1p1

Sal/c6/ano. (2020). Di Surabaya, Sebanyak 497 Orang Di-PHK dan 1.594 Orang Dirumahkan. Jawapos.

https://www.jawapos.com/surabaya/04/06/2020/ di-surabaya-sebanyak-497-orang-di-phk-dan-1594-orang-dirumahkan/

Santouridis, I., \& Kyritsi, M. (2014). Investigating the Determinants of Internet Banking Adoption in Greece. Procedia Economics and Finance, 9(Ebeec 2013), 501-510. https://doi.org/10.1016/s2212-5671(14)00051-3

Yasa, N. N. K., Ratnaningrum, L. P. R. A., \& Sukaatmadja, P. G. (2014). the Application of Technology Acceptance Model on Internet Banking Users in the City of Denpasar. Jurnal Manajemen Dan Kewirausahaan, 16(2), 93-102. https://doi.org/10.9744/jmk.16.2.93-102

Zhang, T., Lu, C., \& Kizildag, M. (2018). Banking "on-the-go": examining consumers' adoption of mobile banking services. International Journal of Quality and Service Sciences, 10(3), 279-295. https://doi.org/10.1108/IJQSS-07-2017-0067

Zuraya, N., \& Puspaningtyas, L. (n.d.). Mandiri Syariah Revisi Target Pertumbuhan 2020. Retrieved October 15, 2020, from https://republika.co.id/berita/qflu2v383/mandirisyariah-revisi-target-pertumbuhan-2020 